\title{
Opportunism, Corruption and the Multinational Firm's Mode of Entry ${ }^{1}$
}

\author{
Stéphane Straub ${ }^{2}$ \\ University of Edinburgh
}

December 1, 2007

\footnotetext{
${ }^{1}$ I thank the editor Linda Tesar and two anonymous referees for helping improve this paper, as well as Jean-Paul Azam, Jean-Claude Berthélemy, Eliana La Ferrara, Jean Tirole and Michael Warlters for helpful comments, and the Research Department of the Inter-American Development Bank for providing some of the data. A special thought goes to my late advisor Jean-Jacques Laffont, as this piece of work was the first chapter of my Ph.D. dissertation and was much inspired by him. He is greatly missed.

${ }^{2}$ Correspondence: Stéphane Straub, Department of Economics, University of Edinburgh, William Robertson Building, 50 George Square, Edinburgh EH8 9JY, UK. Tel: +44 131650 8359. Fax: +44 131650 4514. Email: stephane.straub@ed.ac.uk.
} 


\begin{abstract}
The paper develops a theoretical approach to the boundaries of the multinational firm in the context of institutional constraints in host countries, focusing especially on corruption. The model incorporates two types of corruption: petty bureaucratic corruption and high-level political corruption. The model predicts that -in the absence of corruption- multinational firms will prefer FDI (internal expansion with strong control rights) to debt (arm's length expansion with loose control rights), the weaker the host country's ability to commit. However, both types of corruption shift the trade-off marginally toward debt. Cross-country panel empirical evidence supports these conclusions. Corruption has a second order marginal effect and matters mostly through its interaction with political risk.

JEL Codes: F2, F3. Keywords: FDI, Debt, Multinational firms, Capital flows, Expropriation, Corruption.
\end{abstract}


"Why, exactly, did United Fruit want to own Central American banana plantations (and often the republics in which they were located), while many US sellers of personal computer clones seem reconciled simply to contract with their Korean or Taiwanese suppliers? The answer is not at all obvious from the international economics literature." Krugman (1995), pp. 1274-75.

\section{Introduction}

This paper's objective is to offer a simple theory of the multinational firm's boundaries in the presence of institutional constraints, focusing specifically on the problem of corruption. Additionally, it provides some preliminary empirical tests supporting the conclusions of the model, using data on the cross-country composition of capital flows for the 1985-1999 period.

Whenever a firm engages in multinational expansion, it faces a fundamental trade-off between exploiting its potential advantages internally by investing directly in foreign countries (FDI) vs. expansion through arm's length contracts. From a corporate finance perspective, FDI is not the investment itself (the plant, the assets) but a particular way to finance this investment through equity and internal loans, that induces tighter control rights on the subsidiary. An alternative way for the multinational firm to take advantage of its specific assets would be to sell them directly to the host country or to engage in a licensing agreement, in which case it would choose to hold a claim with looser control rights on the project. I define these arm's length transactions as debt contracts. ${ }^{1}$

Whether the firm prefers holding equity (FDI) or debt depends on the nature of the project and on the risks it faces. ${ }^{2}$ These must be understood broadly as including specific industrial or climatic risks, as well as factors resulting from the nature of the information available to the parties and the institutional structure of the host country. Default on debt by sovereign borrowers, expropriation of investments, and cases of corruption are well known problems plaguing relationships between foreign investors and host countries, particularly in less developed countries (LDCs). We should expect

\footnotetext{
${ }^{1}$ The internationally accepted definition of FDI from the IMF's 1993 Balance of Payments Manual states: "Foreign Direct Investment is net inflows of investment to acquire a lasting management interest (10 percent or more of voting stock) in an enterprise operating in an economy other than that of the investor. It is the sum of equity capital, reinvestment of earnings, and short- and long-term intercompany loans between parent firms and foreign affiliates." In what follows I use the term debt to design any claim with weaker control rights than FDI.

${ }^{2}$ See Hausmann and Fernández-Arias (2000) for an interesting discussion on this.
} 
these features to have a significant impact on the financial decision of the firms seeking to invest abroad.

There is a vast literature on foreign investment in the presence of political risk. Eaton and Gersovitz (1984) first introduced the idea that intangible assets would limit the host country's incentives to expropriate foreign direct investments. Doyle and Van Wijnbergen (1994) consider the rationale for tax holidays for foreign multinational firms in a sequential bargaining framework, and Thomas and Worrall (1994) endogenize the size of the direct investment and examine its dynamic behavior when investors are bound to rely on self-enforcing contracts. Relatedly, Bond and Samuelson (1989) propose a two-period model in which the level of commitment of the host country is endogenized, and the firm can respond by altering the capital intensity of its investment. These contributions share the characteristic that they study the amount, input structure and timing of FDI when faced with institutional constraints, but do not consider alternative ways of transferring capital.

Albuquerque (2003) extends Thomas and Worrall's framework to allow precisely for different types of investment (FDI or portfolio flows) and the possibility of exogenous termination of contracts. Assuming the inalienability of part or all of FDI investments, coupled with the imperfect enforcement of international financing contracts, his model reaches two main conclusions. First, financially constrained countries, which empirically can also be seen as the ones characterized by higher political risk, receive a higher share of FDI. Second, FDI commands a lower default premium and is thus less volatile than other type of flows. Similarly, Schnitzer (2002) examines the trade-off between FDI and debt in the presence of sovereign risk and finds that FDI is more likely to prevail when it allows for a better exogenous external option, the project is risky and the foreign investor has a greater efficiency advantage in running the project. ${ }^{3}$

Recognizing the pivotal role of the risk of expropriation, the present paper starts from a simple model yielding a conclusion similar to Albuquerque (2003), namely that FDI is more likely in the context of higher political risk. The common building block is the inalienability of part of the direct investment, or equivalently the existence of an outside option for this type of investment in case of expropriation. The paper then goes on to model explicitly the impact of corruption on foreign investment. In doing so, it fills a gap since the existing theoretical literature has not yet explicitly modeled corruption as part of the ownership decision in international investment,

\footnotetext{
${ }^{3}$ Related contributions include Janeba (2002), Goldstein and Razin (2002), Fosfuri (2000), Kraay, Loayza, Serven and Ventura (2004) and Tirole (2003), among others.
} 
despite mounting empirical evidence that corruption is one of the factors seriously affecting the conditions facing foreign investors.

The model's basic building block draws on Williamson (1975), Hart and Moore (1990) and Hart (1995): By undertaking a specific action (here a sunk investment to retain some "secret" on the technology) the firm chooses ex ante the financial structure of its investment, which has an influence on its bargaining position in subsequent periods. The incompleteness of contracts, arising from the possibility that the host country may renege on its commitment, implies that the returns from the relationship depend precisely on this ex post bargaining position, so the ownership structure's decision is not neutral.

Corruption in the context of capital flows and foreign investment is a multifaceted phenomenon. ${ }^{4}$ I argue that it can usefully be categorized in two main types, namely bureaucratic petty corruption, akin to outright extortion, and high-level political corruption. To allow political corruption to arise endogenously, I assume that the value of the flow of externalities is known to the investing firm, but not to the host country. I model the bargaining game between the firm and the government by extending under asymmetric information a simple game form implementing the Nash bargaining solution, originally proposed in a complete information setting by Howard (1992) and Osborne and Rubinstein (1994). In this game-theoretic setting, I assume that an expert is in charge of reducing the asymmetry of information on behalf of the government, in the spirit of the principal-agent model of corruption (see Laffont and Tirole, 1991).

In a nutshell, the conclusions of the model point to the following findings. Petty bureaucratic corruption acts as a tax and may shift the choice of foreign investors toward debt. Political corruption, on the other hand, affects investment through its interaction with the risk of expropriation, actually reducing the effect of the latter. This is because corruption induces the expert to make more effort to learn the firm's type and extract its rent, thereby reducing the informational advantage of firms choosing FDI in case of expropriation. Empirical tests support the view that corruption matters mostly through this second order countervailing effect on the risk of expropriation. Political risk remains the foremost institutional driver behind foreign investors' financing structure choice, but, intuitively, corruption conditions its intensity. One conjecture is that previous empirical contributions that supported a separate role for corruption failed to control for political risk, thereby attributing part of its effects to the corruption variable.

Section 2 documents and discusses the two different types of corrupt

\footnotetext{
${ }^{4}$ I thank two anonymous referees and the editor for stressing this aspect.
} 
constraints on foreign investment. Section 3 presents the model, setting up the basic trade-off between FDI and debt with credit constraint and lack of commitment, and introducing asymmetric information and the two types of corruption in this framework. Section 4 then presents the empirical evidence and Section 5 concludes.

\section{Corruption and Foreign Investment}

\section{Bureaucratic Corruption}

I distinguish between two types of corruption. Bureaucratic corruption refers to corrupt demands faced by firms once settled in the foreign country. These demands, in the form of excessive administrative requirements, red tape and systematic bribe extraction by low-level government officials, are the manifestations of corruption most commonly mentioned in the literature. ${ }^{5}$ Morisset and Lumenga Neso (2002) document extensively the administrative barriers faced by foreign investors in a sample of 32 developing countries, listing them in 3 categories: Entry approvals; land, site development and utility; and operational requirements. They show that such requirements are pervasive and that higher costs and delays are strongly correlated with the prevailing level of corruption, as measured by the Transparency International index. Rose-Ackerman (1999) also offers numerous examples of such corruption.

I model the multinational firm dealing with a potentially corrupt local bureaucracy by assuming that government officials in charge of allocating a license-type good may ask for a bribe and that foreign firms are at a disadvantage compared to local firms, because of their lack of personal connections and knowledge of the local customs. Furthermore, in this case of petty corruption, bureaucrats are likely to have only limited information on the firm's profit, so I assume that they chose the amount of the bribe by maximizing their return in a context in which they risk being detected and punished.

\section{Political Corruption}

Political corruption emanates from the interaction between the multinational firm and a host-country government official in charge of assessing the value of the investment and of negotiating the incentive package to be granted to the incoming investors. In this case, the firm and local counterparts are equally involved in the dishonest deals.

There are also plenty of illustrations of this type of behavior. While an adviser to a Latin American government a few years ago, I observed that

\footnotetext{
${ }^{5}$ See for example Wei (2000), Wei and Wu (2001) and Smarzynska and Wei (2000)
} 
representatives of foreign firms looking for investment opportunities in the country would almost invariably be attended by high-ranking officials. It appeared that such practices often led to some rent extraction, for example in the form of future joint ventures with officials' front-men or by securing employment for relatives in the newly established firms. ${ }^{6}$

Firms find an interest in entering such deals if they perceive that the resulting connections may eventually help them secure specific markets or investment opportunities, for example in procurement or privatization processes. ${ }^{7}$ Press articles regularly report stories of firms buying their way into foreign oil, gas or telecommunication markets. ${ }^{8}$

The main difference between petty bureaucratic and high-level political corruption is that the former takes the form of outright extortion and imposes a pure loss on the firm, while the latter generates the opportunity of a gain for both the government and the firm.

I model the second approach by assuming that a local politician is in charge of evaluating the value of the project. ${ }^{9}$ Conceptually, the politician is an intermediate agent between the principal and the firm, whose contractual role is to reduce the asymmetry of information on behalf of the principal. One possibility is a government political appointee trying to maximize welfare (note that non fully benevolent objective function can be accommodated under this approach). Alternatively, the principal can be thought of as the public, represented by the idea embodied in the constitution or in the grand contract with the government in charge, in which case the politician can even be the ruler himself as in some of the examples above (see Laffont and Tirole, 1993).

\footnotetext{
${ }^{6}$ See Hines (1995) for empirical evidence that "payroll" type corruption is indeed important.

${ }^{7}$ See Rose-Ackerman (1999) for examples of firms bribing high-level officials from Greece, Argentina, Peru, Zaire, Ivory Coast, Thailand and Slovakia. Hines (1995) shows that nearly half of 2,219 US business executives surveyed find no ethical impediment in paying bribes to further their company's objectives. Further discussion can be found in Kaufmann (2004) and Transparency International's press releases, such as the Bribe Payers Index at http://www.transparency.org.

${ }^{8}$ Recent examples include the involvement of a French oil company (formerly Elf, now merged with Total) in cash payments to high government officials (including presidents) in Nigeria and Gabon; commissions paid by a consortium including French Technip, Italian Snamprogetti and US KBR, filial of Halliburton, to secure contracts in Nigeria; bribes paid by the French electronic group Thales in Argentina in the 1990s; and accusations of corruption against the French firm Alcatel, the Spanish electric equipment provider Inabensa and Swedish Ericsson, to secure telecommunication contracts in Costa Rica (The Economist, 13/11/03; Le Monde, 16/10/04 and 05/11/04).

${ }^{9}$ Note that local firms can similarly be engaging in collusion over state subsidies, without affecting the results of the model.
} 
The politician enjoys decentralized power in the form of information not directly verifiable by the principal and can then take advantage of her position to make a side contract with the investor, sharing the potential information rent in exchange for a favorable report. This is modelled in a hard information setting à la Tirole (1992), in which the politician generates a verifiable signal on the project with some positive probability and ensuring her honest behavior requires costly incentive payments. I extend this setting to model the politician's choice of the supervision intensity as an effort variable.

\section{The Model}

Consider the following three period model. In country L, local firms produce a good with a constant return to scale technology of marginal $\operatorname{cost} \mathrm{c}_{L}$. This good is consumed by local consumers who have a downward sloping demand function. As a result of investment in $R \& D$ and long term experience in managerial best practice, a foreign firm $\mathrm{F}$ has developed an alternative technology, which allows it to produce the same good at a lower marginal cost $\mathrm{c}_{F}$, and now wants to enter country L's market.

Formally, and with the subscript $\mathrm{t}=0,1,2$ referring to time, we have:

- $\mathrm{t}=0$, the benchmark situation in country $\mathrm{L}$, with only indigenous producers of cost $c_{L}$.

$-\mathrm{t}=1$, the situation in $\mathrm{L}$ when the improved technology $\left(\mathrm{c}_{F}\right)$ is first introduced and competes with high cost producers $\left(c_{L}\right)$.

$-\mathrm{t}=2$, the situation in $\mathrm{L}$ when the improved technology $\left(\mathrm{c}_{F}\right)$ competes with local producers who have benefited from technological spillovers $\left(\operatorname{cost} \mathrm{c}_{L S}<\mathrm{c}_{L}\right){ }^{10}$

In each period, aggregate welfare is given by $W_{t}=S_{t}^{C}+\Pi_{t}^{L}+\Pi_{t}^{F}$, where $\Pi_{t}^{L}$ (resp. $\Pi_{t}^{F}$ ) is the profit of firms using the "local" (resp. "foreign") technology, and $S_{t}^{C}$ denotes consumer surplus. Assuming there is no discounting, the net benefit of the introduction of the technology is thus given by ${ }^{11}$ :

$$
G=\left(W_{1}-W_{0}\right)+\left(W_{2}-W_{0}\right) \equiv G_{1}+G_{2} .
$$

\footnotetext{
${ }^{10}$ See Blomström and Kokko (1996) for a discussion of spillovers arising from the operations of multinational corporations abroad.

${ }^{11} G$ can be disentangled into a competition and a technological effect. For simple downward sloping demand functions, it is easily shown that $G$, the sum of both effects, is always positive. We simply use the fact that higher spillovers imply a higher global value of the project.
} 
The parties are risk neutral and the total surplus is divided among them according to a Nash bargaining process. In a world of complete contracting, the firm would simply sell the blueprint of the technology to country L, based on its total value. From now on, I call this the "Debt" option, in the sense that the country (or some local firm) simply contracts debt to buy the technology and the necessary inputs to make it work (machines, management), possibly collateralized by its expected gain from this acquisition, and sets up a locally owned firm endowed with the new production process.

Alternatively, the firm may choose to engage in FDI. In this case, it will have to pay in period 1 a sunk cost $K$. This is the cost of adapting to different business conditions, finding local partners and counterparts, dealing with local bureaucrats, etc. It is greater than it would be for the host country (or some local investor) who has better knowledge of local conditions and better access to the local administration. On the other hand, the firm keeps the property rights to the technology. ${ }^{12}$

I assume that country L is likely to be credit constrained. In this case, a possible alternative is for the firm to sell its technology against the promise of partial payments in each period, according to the realization of benefits. Then, the surplus from a debt contract is shared in each successive period, so that global payoffs are as follows:

$$
U_{D E B T}^{L}=U_{D E B T}^{F}=\frac{1}{2} G_{1}+\frac{1}{2} G_{2},
$$

while in the case of FDI, they are

$$
U_{F D I}^{L}=U_{F D I}^{F}=\frac{1}{2}\left(G_{1}-K\right)+\frac{1}{2} G_{2} .
$$

Hence, in a world with perfect information and no commitment problems, debt is always more efficient. However, if the risk of contract repudiation exists, country L may renege on its commitment at the beginning of the second period and force a renegotiation. ${ }^{13}$ Considering for example that

\footnotetext{
${ }^{12}$ For simplicity, I assume that the efficiency of the new firm in the host country and the resulting spillovers for the local industry are the same regardless of the way the technology is introduced. On the one hand, a subsidiary may benefit from specific spillovers from the parent company, that would not accrue to a locally owned firm. On the other hand, local entrepreneurs may benefit from better knowledge and information about the business conditions in their country (see Schnitzer, 2002).

${ }^{13}$ As stated in Eaton and Gersovitz (1984), to have expropriation actually occurring, there must be some randomness, which is resolved between the time of investment and the expropriation decision. Otherwise, in a deterministic setting, investors simply refrain from doing investment that they anticipate will be expropriated, so the effect is on the size of investments but expropriation never occurs.
} 
each period of the model lasts for several years, the assumption of imperfect long term commitment arises naturally from possible changes at the head of government or other shifts in the environment.

I assume that expropriation arises with positive probability $\gamma$, followed by a renegotiation at $t=2$ in which the status quo levels depend on the ownership structure. ${ }^{14}$ In the case of debt, the firm has a status quo utility level of zero, so the country appropriates the whole surplus. In the case of FDI, the investor faces the risk of outright expropriation (e.g. through the nationalization of the productive assets), but it is also exposed to a more subtle form of expropriation, in which the host country manages to capture the rents generated by the subsidiary through specific actions like modifications of the tax schedule or tariff duties. ${ }^{15}$ In this case, the firm keeps the property rights over the subsidiary and can recover part of its second period profits, for example shifting some of its subsequent production back to another international location or through accounting gimmicks. ${ }^{16} \mathrm{I}$ simply assume that the firm retains $\theta \Pi_{2}^{F}$, where $\theta<1$.

The outcome of the bargaining process becomes the following. In case of debt, the first period surplus $G_{1}$ is divided evenly, while in the second period in case of renegotiation the firm receives nothing with probability $\gamma$, hence:

$$
\begin{aligned}
U_{D E B T}^{L} & =\frac{1}{2} G_{1}+\frac{1}{2}(1+\gamma) G_{2}, \\
U_{D E B T}^{F} & =\frac{1}{2} G_{1}+\frac{1}{2}(1-\gamma) G_{2} .
\end{aligned}
$$

In case of FDI, at the beginning of period 2 the status quo payoffs of the firm and the host country are $\theta \Pi_{2}^{F}$ and $G_{2}-\theta \Pi_{2}^{F}$ respectively. The outcome in this case is:

\footnotetext{
${ }^{14}$ I keep $\gamma$ exogenous to maintain the model tractable when introducing corruption. One way to endogenize it would be to allow the firm to chose the quality of the technology it transfers (see Fosfuri, 2000, and Bond and Samuelson, 1989). Alternatively, one could assume that expropriation occurs only when $G_{2}-\theta \Pi_{2}^{F}>\frac{1}{2} G_{2}$, as signaled by a referee. The results of the paper would be qualitatively unaltered. Note that in practice, political expropriations occur for reasons that are at least partly orthogonal to strict economic considerations, justifying the exogeneity of $\gamma$.

${ }^{15}$ See Tirole (2003) for an analysis of the common agency issues involved, as policy decisions depend on the FDI-debt choices of many firms.

${ }^{16}$ See Schnitzer (2002) for a more detailed discussion and a model where both cases of expropriation and an exogenous outside option for FDI are considered. Janeba (2002) endogenizes this outside option by considering that firms may invest simultaneously in two countries and use the threat to shift production from one to the other as a disciplining device for governments.
} 


$$
\begin{aligned}
U_{F D I}^{L} & =\frac{1}{2}\left(G_{1}-K\right)+\frac{1}{2}(1+\gamma) G_{2}-\gamma \theta \Pi_{2}^{F}, \\
U_{F D I}^{F} & =\frac{1}{2}\left(G_{1}-K\right)+\frac{1}{2}(1-\gamma) G_{2}+\gamma \theta \Pi_{2}^{F} .
\end{aligned}
$$

The trade-off faced by the firm between the debt and the FDI option is given by:

$$
F D I \succ D e b t \Leftrightarrow \gamma \theta \Pi_{2}^{F}-\frac{K}{2}>0 .
$$

Equation (6) shows that debt is not always preferred by the firm and provides a first prediction, namely that a higher risk of repudiation makes FDI more likely. ${ }^{17}$ Moreover, the trade-off is more favorable to FDI, the greater the share $\theta$ of second period profits that can be recovered in case of contract repudiation, the greater $\Pi_{2}^{F}$, which is the case when the spillovers are of small magnitude, and the lower the sunk cost $K$. This simple setting is thus consistent with the literature on political risk discussed in the introduction, as well as basic empirical evidence on technological transfers. ${ }^{18}$

In the next section, I analyze how this basic trade-off is affected by the possibility of corruption.

\subsection{Corruption}

In a situation where the foreign firm has developed some specific technology or know-how, it is natural to assume that it has private information concerning its exact characteristics. I model this by assuming an asymmetry of information on the level of spillovers, which are known to the firm but not to the host country.

Assume that the net benefit can take two values $G_{S}$ and $G_{W}$, such that $G_{S}>G_{W}$, with the notation $\Delta G=\Delta G_{2}=G_{S}-G_{W}$. The subscript $S$

\footnotetext{
${ }^{17}$ Note that more sophisticated mechanisms could be envisioned, for example frontloading the firm's share in period 1 in case of debt to push it to choose this type of involvement more often. This would amount to endogenizing the parties' bargaining weights. Again, I do not pursue this line to concentrate on the issue of corruption.

${ }^{18}$ Markusen (1995) reports that most empirical studies support the view that the internalization of technological transfers (i.e. FDI) is more likely for R\&D intensive firms with new and technically complex products. If we take the view that this type of production is characterized by relatively low potential spillovers, because the complexity of its products implies a less intensive linkage with domestic suppliers (which seems to be one key factor for the transmission of externalities, see Blomström and Kokko (1996)), this evidence fits well within our framework.
} 
(resp. $W$ ) stands for strong (resp. weak) second period spillovers and can be said to correspond to the "good type" (resp. "bad type") project. The host country has previous beliefs about the realization of $G$ given by:

$$
\begin{aligned}
& \operatorname{Pr}\left(G=G_{S}\right)=\nu, \\
& \operatorname{Pr}\left(G=G_{W}\right)=1-\nu .
\end{aligned}
$$

\section{The Nash Solution with Asymmetric Information}

To solve the asymmetric information case, I introduce the following complete information extensive game form, which exactly implements the Nash solution. It is a simplified version of Howard (1992), proposed by Osborne and Rubinstein (1994).

The game is a simple three-stage alternated offers bargaining. The first mover (the country) offers a possible agreement $Y=\left(y_{1}, G-y_{1}\right)$. The second mover (the firm) responds to this offer by a counteroffer $X=\left(x_{1}, G-x_{1}\right)$ and a threat to terminate the negotiation. Ex ante, the multinational firm's position runs as follows: "Given your offer, I will quit with probability $1-p$ (thus an ex ante threat). Furthermore, if negotiation continues and you don't accept my counteroffer $X$ and insist in implementing $Y$, there is a probability $1-p$ that I will decline any agreement."

The mechanism which leads the players to choose the Nash solution is intuitive: any initial offer which fails to propose this solution can be met with a "punishment" that leaves the initial player worse off than when he proposes an equal splitting of the pie. This is because if $y_{1}>\frac{G}{2}$, the firm has the possibility to choose a probability $p<1$, so that the negotiation ends with a strictly positive probability. Faced with this threat, it is the country's best strategy to offer the Nash solution and the firm agrees to this choice by choosing $X=Y$ and $p=1$. Of course, the country would never choose $y_{1}<\frac{G}{2}$, since the firm would again choose $X=Y$ and $p=1$. Appendix 1 presents a complete resolution of the game under complete and incomplete information.

There are several reasons why bargaining can be considered a reasonable modeling option for foreign investment. ${ }^{19}$ In a context in which countries strongly compete to attract investors, the discussions between firms and governments can indeed be considered as a bargaining game over a whole array of items that determine the distribution of potential benefits (see Moran, 1998). Firms negotiate tax holidays, subsidies and other supporting measures like the financing of infrastructure relevant to the future plants, e.g.

\footnotetext{
${ }^{19}$ The bargaining approach has been adopted for example by Bond and Samuelson (1989) and Doyle and Van Wijnbergen (1994).
} 
roads, electricity or phone lines, while governments routinely use different mechanisms to try to capture more of the benefits, for example imposing domestic-content, export-performance, joint venture, and technology licensing requirements.

The relevance of bargaining can be linked to the necessary incompleteness of contracts involving sovereign parties (see Eaton and Fernandez, 1995, on sovereign debt). Although the analysis of self-enforcing contracts is important from a positive point of view and has provided fundamental improvements in our understanding of capital flows, the actual occurrence of expropriations and renegotiations gives the indication that, for some reasons, parties find it hard to rely on such contracts.

To see the implication of the asymmetry of information for the bargaining problem, consider again the extensive game form introduced above. When one of the players has private information about his type, it obviously matters whether the informed party moves first or not. To avoid the multiplicity of equilibria inherent to a signaling game, and to keep the model as tractable as possible, I stick to the case where the uninformed party (the host country) moves first. The timing of the bargaining procedure is the same as under symmetric information, with the only difference that now, when choosing $y_{1}$ at the beginning of the game, country L does not know the true value of $G$.

Again, what happens is intuitively clear. If the country chooses $y_{1}=\frac{G_{W}}{2}$, the complete information solution (thus the Nash solution) is implemented with probability $1-\nu$ (when $G=G_{W}$ ), but with probability $\nu$ (when $G=G_{S}$ ) it incurs a loss since its initial offer is less than $\frac{G_{S}}{2}$.

On the other hand, if the country's initial offer is $y_{1}=\frac{G_{S}}{2}$, the complete information solution is now implemented with probability $\nu$ (when $G=G_{S}$ ), but with probability $1-\nu$ (when $G=G_{W}$ ) the offer is too high and the firm replies with $p=\frac{G_{W}}{G_{S}}$ and $x_{1}=\frac{G_{W}}{2}$, so that the country suffers a loss with respect to the Nash solution. Note that in this case both parties are worse off than under complete information, a global loss of efficiency typical of bargaining under asymmetric information.

Furthermore, it is shown in Appendix 1 that an intermediate value of $y_{1}$ is never optimal, so that depending on the value of the parameters, the best choice of $y_{1}$ is given by either $y_{1}=\frac{G_{W}}{2}$ or $y_{1}=\frac{G_{S}}{2}$. Table 1 summarizes the outcome of the game for different values of the parameters.

Table 1: outcome of the bargaining game with asymmetric information. 


\begin{tabular}{|c|c||c|}
\cline { 2 - 3 } \multicolumn{1}{c|}{} & $\nu \leq \frac{G_{W}}{G_{S}+G_{W}}$ & $\nu>\frac{G_{W}}{G_{S}+G_{W}}$ \\
\cline { 2 - 3 } \multicolumn{1}{c|}{} & Host country: $y_{1}=\frac{G_{W}}{2}$ & Host country: $y_{1}=\frac{G_{S}}{2}$ \\
\hline $\operatorname{MNE}\left(G_{S}\right)^{*}$ & $\left(\frac{G_{S}}{2}-\frac{\Delta G}{2}, \frac{G_{S}}{2}+\frac{\Delta G}{2}\right)$ & $\left(\frac{G_{S}}{2}, \frac{G_{S}}{2}\right)$ \\
\cline { 2 - 3 } $\operatorname{MNE}\left(G_{W}\right)^{* *}$ & $\left(\frac{G_{W}}{2}, \frac{G_{W}}{2}\right)$ & $\left(\frac{G_{W}^{2}}{2 G_{S}}, \frac{G_{W}^{2}}{2 G_{S}}\right)$ \\
\hline
\end{tabular}

$* x_{1}=y_{1}, p=1$ (both when $y_{1}=\frac{G_{W}}{2}$ and $y_{1}=\frac{G_{S}}{2}$ ).

** $x_{1}=y_{1}, p=1$ (if $\left.y_{1}=\frac{G_{W}}{2}\right) ; x_{1}=\frac{G_{W}}{2}, p=\frac{G_{W}}{G_{S}}\left(\right.$ if $\left.y_{1}=\frac{G_{W}}{2}\right)$.

I now consider how the different types of corruption introduced above will affect the FDI-debt trade-off. ${ }^{20}$

\subsection{Investment under Bureaucratic Corruption}

Consider a situation in which local bureaucrats are in charge of attributing licenses to firms, for example authorizing imports of specific inputs or delivering health and safety certificates. As discussed above, these low-level officials are unlikely to be have detailed information on the firms they deal with, so I simply assume that in period 2, they require from the firm that has chosen FDI a fixed bribe $B$ in order to issue the relevant license. ${ }^{21}$

Assume that bureaucrats risk being detected and punished with probability $\tau(B)$, with $\tau^{\prime}>0$ and $\tau^{\prime \prime} \geq 0$. One explanation is that the firms' willingness to denounce corrupt demands is an increasing function of their amount. Alternatively, huge bribes are simply more difficult to hide, because they involve observable transfers of wealth or they result in public employees enjoying acquisitive power beyond what their salaries would permit. These cases are thus more likely to draw media attention and be brought to light.

Accordingly, bureaucrats choose $B$ by maximizing a return function of the type:

\footnotetext{
${ }^{20}$ Ex ante, investors have superior information on the quality of their project, irrespective of the type of ownership chosen. Alternatively, a corporate finance perspective is likely to put emphasis on the fact that debtors would enjoy superior information on some aspects of a debt contract. However, the contradiction is only apparent. As will become clear below, FDI does generate an additional informational edge for investors in case of renegotiation. Thus, in relative terms, debtors do know more about the claim (they are a lesser informational disadvantage) in case of debt. Other types of asymmetries could be envisioned, for example about local demand conditions, in which case the government could be the one having private information. In this case, a similar relative effect would hold and debtors would indeed enjoy the stronger informational advantage in the case of debt.

${ }^{21}$ This does not mean that local firms are not themselves subject to bribes, but that foreign firms are better targets for corrupt officials, because of their relative ignorance of the local rules and their lack of personal connections for example.
} 


$$
\max _{B}(1-\tau(B)) B
$$

In a context more prone to corruption, i.e. one in which the probability of detection is lower for a given $B$, the above maximization problem leads bureaucrats to demand higher bribes.

In order to see how bureaucratic corruption affects the trade-off between FDI and debt, first consider the complete information case. Clearly, the prospect of giving away an amount $B$ does not modify the status quo of the firm when faced with an attempt of expropriation, which in any case is given by $\theta \Pi_{2}^{F}$. However, note that when $B>\frac{1}{2}(1-\gamma) G_{2}+\gamma \theta \Pi_{2}^{F}-\theta \Pi_{2}^{F}=$ $(1-\gamma)\left[\frac{1}{2} G_{2}-\theta \Pi_{2}^{F}\right]$, the bribe exceeds the firms profits minus its outside option, so it will choose to leave the country. ${ }^{22}$

The firm's payoffs to engage in FDI and debt respectively are then given by:

$$
\begin{aligned}
U_{F D I}^{F} & =\frac{1}{2}\left(G_{1}-K\right)+\frac{1}{2}(1-\gamma) G_{2}+\gamma \theta \Pi_{2}^{F}-B \text { if } B \leq(1-\gamma)\left[\frac{1}{2} G_{2}-\theta \Pi_{2}^{F}\right], \\
& =\frac{1}{2}\left(G_{1}-K\right)+\theta \Pi_{2}^{F} \quad \text { otherwise. } \\
U_{D E B T}^{F} & =\frac{1}{2} G_{1}+\frac{1}{2}(1-\gamma) G_{2} .
\end{aligned}
$$

The trade-off then becomes:

$$
\begin{aligned}
F D I \succ \text { Debt } & \Leftrightarrow \gamma \theta \Pi_{2}^{F}-\frac{K}{2}-B>0 \text { if } B \leq(1-\gamma)\left[\frac{1}{2} G_{2}-\theta \Pi_{2}^{F}\right], \\
& \Leftrightarrow \gamma \theta \Pi_{2}^{F}-\frac{K}{2}-\frac{1}{2}(1-\gamma) G_{2}>0 \text { otherwise. }
\end{aligned}
$$

Under asymmetric information, the results are similar. Consider first the case $\nu \leq \frac{G_{W}}{G_{S}+G_{W}}$. With FDI, The firm's second period surplus is given by $\frac{1}{2}(1-\gamma)\left(G_{2, S}+\Delta G_{2}\right)+\gamma \theta \Pi_{2, W}^{F}$ for a good type firm, and by $\frac{1}{2}(1-\gamma) G_{2, W}+$ $\gamma \theta \Pi_{2, W}^{F}$ for a bad type one.

\footnotetext{
${ }^{22}$ While the empirical literature mostly focuses on how corruption may keep investors away from specific countries, stories of foreign investors forced to leave by excessive corruption make regular headlines in developing countries. This will be the case if myopic bureaucrats place demands such that they extinguish the source of the bribe. If firms anticipate the level of $B$ as in the present framework, this would never happen, as they would just refrain from choosing FDI. However, one can envision unexpected ex post shocks leading to an increase in corruption, so that firms that have chosen FDI are pushed toward the exit.
} 
Defining $\underline{B} \equiv \frac{1}{2}(1-\gamma) G_{2, W}+\gamma \theta \Pi_{2, W}^{F}-\theta \Pi_{2, W}^{F}$, and $\bar{B} \equiv \frac{1}{2}(1-\gamma)\left(G_{2, S}+\right.$ $\left.\Delta G_{2}\right)+\gamma \theta \Pi_{2, W}^{F}-\theta \Pi_{2, S}^{F}$, as the thresholds below which bureaucrats are able to extract bribes from both types of firms and from the good type one only respectively, the FDI-debt trade-off in the three possible cases is given $b^{23}$ :

$F D I \succ D e b t \Leftrightarrow$

- $\gamma \theta \Pi_{2, W}^{F}-\frac{K}{2}-B>0$, if $B \leq \underline{B}$,

- $\nu \gamma \theta \Pi_{2, W}^{F}-(1-\nu)\left[\frac{(1-\gamma) G_{2, W}}{2}-\theta \Pi_{2, W}^{F}\right]-\frac{K}{2}-\nu B>0$, if $\underline{B} \leq B \leq \bar{B}$,

- $\nu \theta \Pi_{2, S}^{F}+(1-\nu) \theta \Pi_{2, W}^{F}-\frac{(1-\gamma)}{2}\left[\nu\left(G_{2, S}+\Delta G_{2}\right)+(1-\nu) G_{2, W}\right]-\frac{K}{2}>0$, if $B>\bar{B}$.

Interestingly, corruption favors a shift toward debt but, as the proneness to corruption increases, the marginal effect is decreasing and eventually vanishes. ${ }^{24}$

I summarize the results of this section in the following proposition.

Proposition 1 Petty bureaucratic corruption, in which low-level public officials uninformed about firms' true profitability place fixed bribe demands, shifts the trade-off of incoming investors toward debt. Moreover, the marginal effect of this type of bribery is smaller for larger bribe demands, and there is a bribe threshold above which it becomes nil.

The simple intuition driving this result is that bureaucratic corruption acts as a tax on FDI, thus making debt more desirable. However, if expected corruption exceeds some threshold, debt always dominates and corruption has no marginal effect on the ownership decision of foreign investors.

\subsection{Investment under Political Corruption}

As discussed in section 2, consider a politician under a (possibly implicit) contract with a principal (the people themselves or the highest tier of government) maximizing some welfare objective function. The position of the politician gives her access to information on the true type of the firm not

\footnotetext{
${ }^{23}$ If $\underline{B} \leq B \leq \bar{B}$ the bribe exceeds the bad type firm's profits minus its outside option and is only paid by the good type. If $\bar{B} \leq B$ bureaucrats completely extinguish the potential source of bribe. If bureaucrats anticipate that there is an upper bound on firms' willingness to pay bribes, the third case would disappear.

${ }^{24}$ When $\nu>\frac{G_{W}}{G_{S}+G_{W}}$, the expressions for the trade-off are slightly modified but the conclusions are strictly similar, so we do not present the results to save space.
} 
directly verifiable by this principal, allowing here to extract the asymmetric information rent of the firm.

Formally, consider a supervision technology à la Tirole (1992), where the politician receives with some positive probability $\xi$ a verifiable signal $\sigma$ on the good type investor (see Figure A1 in Appendix 2). Collusion only occurs when $\nu \leq \frac{G_{W}}{G_{S}+G_{W}}$, which is the only case where the investor enjoys an information rent, so I shall concentrate on this case. ${ }^{25}$ When the politician detects a good type project $\left(G_{S}\right)$, she may collude with the firm to report the project as being of the bad type $\left(G_{W}\right)$, and share the potential bargaining surplus $\frac{1}{2} \Delta G$. If collusion occurs, I assume that the politician has all the bargaining power and receives the whole surplus. ${ }^{26}$ Moreover, when the firm transfers an amount $t$, the politician receives only $k t$, where the deadweight loss parameterized by $k \leq 1$ corresponds to the transaction cost of collusion. ${ }^{27}$ Thus, to prevent collusion, the politician needs to be given an incentive payment $s=k \frac{1}{2} \Delta G$ when she reveals a good type project.

Consider furthermore that in order to have a signal with probability $\xi$, the politician must exert an effort, which has a disutility $\Psi(\xi)\left(\Psi^{\prime}(\xi)>\right.$ $0, \Psi(\xi)^{\prime \prime}>0$ ), because, say, it is time consuming and her opportunity cost is high. The politician is rewarded with a payment $r$ for each dollar that her report allows to recover. She will thus choose a level of effort so as to solve:

$$
\max _{\xi} \xi r \frac{\Delta G}{2}-\Psi(\xi)
$$

Taking a simple functional form $\Psi(\xi)=\frac{\Delta G}{2} \frac{\xi^{2}}{2}$ for the purpose of normalization, it comes immediately that $\xi^{*}=r$.

Anticipating this, the optimal contract with the politician will set the reward $r$ so as to maximize:

$$
\max _{r} \xi \frac{\Delta G}{2}-\xi r \frac{\Delta G}{2}=r \frac{\Delta G}{2}-r^{2} \frac{\Delta G}{2},
$$

where the first term is the gain due to the report occurring with probability $\xi$, and the second term is the cost of the incentive payment to the politician. Thus, $r^{*}=\frac{1}{2}$, and an informative report is received with probability $\xi^{*}=\frac{1}{2}$.

\footnotetext{
${ }^{25}$ When $\nu>\frac{G_{W}}{G_{S}+G_{W}}$, asymmetric information and the politician intervention have no effect on the trade-off between FDI and debt (see Appendix 2).

${ }^{26}$ Considering that the politician and the firm get shares of the surplus equal to $\alpha$ and $1-\alpha$ respectively, would not change the following results.

${ }^{27} k$ can be considered to capture both material difficulties in realizing illegal side payments and psychological traits of the corrupt agents, like their relative honesty or their fear to be caught. See Laffont and Tirole (1991) for a discussion.
} 
Consider now the case where the politician is potentially corrupt. We have seen that she receives $s=k \frac{1}{2} \Delta G$ if the side contract with the firm is enforced. The maximization program of the politician becomes therefore:

$$
\max _{\xi} \xi\left[\max (k, r) \frac{\Delta G}{2}\right]-\Psi(\xi),
$$

where the side contract prevails if $k>r$ and a truthful report is made otherwise. The politician will thus choose $\xi^{*}=\max (k, r)$. Considering this, the optimal $r$ is $r^{*}=\frac{1}{2}$ as long as $k<\frac{1}{2}$ and $r^{*}=k$ otherwise. As a result, $\xi^{*}=\frac{1}{2}$ when $k<\frac{1}{2}$ and $\xi^{*}=k$ otherwise.

As $k$ increases, i.e. as the environment becomes more prone to corruption because of lower transaction costs, the intensity of monitoring $\xi^{*}$ will thus also increase.

The timing of the events is given in Figure 1.

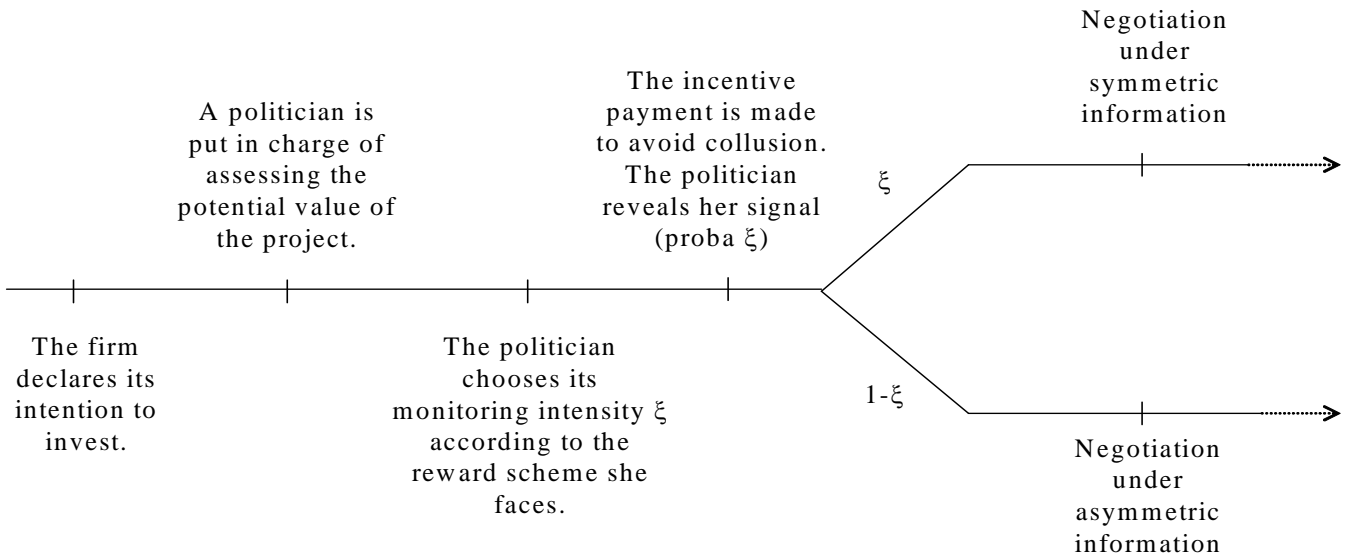

Figure 1: Timing

In this simple informational structure, the collusion proofness principle holds, so it is always profitable to pay the politician in exchange for a hard signal that the project is good. ${ }^{28}$ We can now look at the consequences for the trade-off between debt and FDI. Three cases will occur:

- Case 1: with probability $\nu \xi$, the project is good, the politician has a signal $G_{S}$, reveals it, and the full information solution is implemented.

- Case 2: with probability $\nu(1-\xi)$, the project is good, the politician has no signal, and the asymmetric information solution prevails.

- Case 3: with probability $1-\nu$, the project is bad, the politician has no signal, and the asymmetric information solution prevails. Note however

\footnotetext{
${ }^{28}$ See for example Tirole (1992). Heterogeneity of politicians would be needed to have corruption at equilibrium.
} 
that this case is similar to the complete information one, since the country offers $\frac{G_{W}}{2}$ and the firm has no rent anyway.

With two types of project and complete information, the trade-off between FDI and debt is given by:

$$
F D I \succ D e b t \Leftrightarrow \gamma\left(\nu \theta \Pi_{2, S}^{F}+(1-\nu) \theta \Pi_{2, W}^{F}\right)-\frac{K}{2}>0,
$$

where $\Pi_{2, S}^{F}$ (resp. $\Pi_{2, W}^{F}$ ) corresponds to the second period profit of the incoming firm if the spillover is strong (resp. weak). Under asymmetric information, the trade-off becomes (see Appendix 2):

$$
F D I \succ D e b t \Leftrightarrow \gamma \theta \Pi_{2, W}^{F}-\gamma \xi \nu \theta\left(\Pi_{2, W}^{F}-\Pi_{2, S}^{F}\right)-\frac{K}{2}>0 .
$$

Now, when renegotiation happens, with probability $1-\nu \xi$ (the sum of the probabilities of cases 2 and 3 above) the host country is uninformed about the firm's type. In particular, with probability $\nu(1-\xi)$ (case 2 ), the good type is able to mimic the bad one and receives an extra gain from negotiating under asymmetric information, thanks to a better status quo position $\left(\theta \Pi_{2, W}^{F}\right.$ instead of $\left.\theta \Pi_{2, S}^{F}\right) \cdot{ }^{29}$ Note that it is the interaction of the risk of repudiation (which induces renegotiation with a certain probability) and of asymmetric information and potential corruption (which modifies the firm's bargaining position in this renegotiation) that together shift the tradeoff. Since $\Pi_{2, W}^{F}$ is greater than $\Pi_{2, S}^{F}$, it appears that an increase in the probability $\xi$ that the politician has a signal on the good project, shifts the trade-off marginally toward debt. When the politician chooses the intensity of monitoring according to her potential reward, $\xi$ is higher in a more corrupt environment. The conclusion is therefore that environments more prone to corruption tend to favor debt relative to FDI.

I summarize the insights from this section in the following proposition:

Proposition 2 An environment more prone to political corruption (lower transaction costs of corruption, thus higher $k$ ) shifts the choice of investment toward debt. Moreover, the effect of this type of corruption is effective through its interaction with the commitment variable $\gamma$.

Corollary 3 An increase in corruption (higher $k$ ) has the effect of diminishing the marginal impact of political risk.

\footnotetext{
${ }^{29} \Pi_{2, W}^{F}$ corresponds to the second period profit of the incoming firm if the spillover is weak, i.e. if the firm retains a greater competitive edge, and is therefore greater than $\Pi_{2, S}^{F}$.
} 
The intuition is as follows. Asymmetric information gives firms choosing FDI an edge in case of expropriation because they can then pretend to have a higher outside option. In a more corrupt environment, this edge becomes less important because officials exert a higher monitoring effort to capture part of the firms' rent as bribe, so their true type is revealed more often. This shifts investors' preferences marginally toward debt, counteracting the effect of political risk.

Technically, under asymmetric information, a good type firm choosing the FDI option is able to mimic a bad type in case of renegotiation and obtain a better payoff. The more corrupt the environment, the higher the politician's monitoring effort and the incentive payments, so complete information prevails more often, thus reducing the interest for the good firm to choose FDI, and shifting the trade-off marginally toward debt.

The next section presents some illustrative empirical evidence.

\section{Empirical Evidence}

\subsection{The Data}

Foreign Direct Investment as a share of total private capital flows. The relative prevalence of FDI in a country's capital flows is measured as the amount of foreign direct investment as a share of total private capital flows, consisting of private debt (commercial bank lending, bonds, and other private credits) and non-debt flows (FDI and portfolio equity investment), using gross inflows data from the IMF's International Financial Statistics Database. ${ }^{30}$ I use average log values for three successive periods: 1985-1989, 1990-1994, and 1995-1999, getting cross-country samples of 68, 84, and 92 observations respectively, and an unbalanced panel covering three periods and 106 countries (See list in Appendix 3).

Risk of contract repudiation and corruption. To capture countrylevel political risk in the sense of lack of commitment, I employ an indicator of the risk of government repudiation of contracts, published in the International Country Risk Guide by the private firm Political Risk Service, Inc. I also use the corruption index from the same source. This is a measure of "corruption within the political system, which distorts the economic and

\footnotetext{
${ }^{30}$ The test proposed here, using aggregated capital flows data, must obviously be seen as preliminary. In particular, it might be argued that not all private capital flows have to do with multinational firms' operations (see a robustness check on this below), and conversely that not all private borrowing is recorded as private capital flows, for example when it is secured by a domestic intermediary or a multilateral agency.
} 
financial environment". Alternatively, to account for the concern that it may rather be capturing political corruption, I use an index of bureaucratic quality, from the same source, as a proxy for bureaucratic corruption.

These indices are available for the years 1985, 1990 and 1995 for all the countries in our sample and, for the sake of interpretation, are rescaled from 0 (less risk, least corrupt) to 10 (more risk, most corrupt). I use beginning of the period values to mitigate potential endogeneity problems.

Other data. ${ }^{31}$ The following control variables are included (again, beginning of the period values are used when applicable): income measured by GDP per capita, the openness of the economy proxied by the ratio of imports to GDP, the size of the economy measured by total GDP, all three (in logs) from the World Bank World Development Indicators; an index of inflation to proxy for macroeconomic stability (a higher value meaning less inflation), from the Inter-American Development Bank; and a set of time-invariant characteristics, including a measure of the value of the subsoil natural wealth of a country and latitude, from the World Bank.

\subsection{Empirical Results}

Following the model, I test a specification of the form:

$$
\begin{aligned}
\text { FDI } / \text { total priv. } \mathrm{K}= & \alpha+\beta_{1} \text { risk }+\beta_{2} \text { corruption } \\
& +\beta_{3} \text { risk }^{*} \text { corruption }+\beta_{4} \text { control var. }+u,(12)
\end{aligned}
$$

where $\beta_{2}$ captures what I called the bureaucratic corruption effect, while $\beta_{3}$ correspond to the political corruption dimension.

Table 2 shows the basic panel estimations, using the ratio of FDI to total private capital flows as dependent variable. The results support the main conclusions above. The previous literature indicates that time-invariant variables (soil and latitude) are important determinants of the composition of capital flows, but the use of these variables rules out fixed-effect estimation. On the other hand, random effect estimation is not the most suitable option for cross-country data. Consequently, equations 1 to 3 are estimated without intercept, while time-invariant variables and regional dummies account for some of the country effects. In columns 4 and 5, fixed effects estimation are performed as a robustness check, excluding time-invariant characteristics and country dummies. In all cases, traditional controls (income, openness, size) are introduced, as well as time dummies, which are meant to capture some key structural evolutions that affected flows of capital during the period

\footnotetext{
${ }^{31}$ Part of this data set was kindly provided by the Inter-American Development Bank Research Department.
} 
under scrutiny, such as the end of the cold war, the launch of the EU single market and the change of attitude towards FDI in developing countries.

(Table 2 here)

The risk of contract repudiation and its interaction with corruption give results consistent with the political corruption story of the model, both variables being of the expected sign and economically significant in all five specifications. For each point increase in the risk index (on a scale from 0 to 10), corresponding to a higher risk of contract repudiation, the share of FDI in total private capital flows increases by between 3 and $4 \%$, while maintaining that risk index constant, a one point variation in the corruption index has an opposite effect of between 0.5 and $0.8 \% .^{32}$

As for the direct effect of corruption, it is as expected in columns 1 and 2 , where we get a negative and significant coefficient, indicating a marginal effect of around $1.5 \%$ for each additional point on the corruption scale of the PRS index. This confirms the idea that corruption has both an indirect effect through its interaction with political risk and a direct one, linked to bureaucratic corruption. Moreover, in column 2, I test the possibility of a decreasing direct marginal effect of corruption, by introducing an interaction between this variable and a dummy equal to 1 for a group of low corruption countries. ${ }^{33}$ The result supports the hypothesis of a lower marginal effect for more corrupt countries (1.7\% against $2.3 \%$ for less corrupt ones). Column 3 presents a similar specification, where the corruption variable is replaced by the bureaucratic quality index. Results are similar overall (the significance of political risk and corruption actually improves), with a significant and negative bureaucratic effect of around 1\% for the group of countries with better institutions. ${ }^{34}$ Note that in all cases, the marginal effect of corruption is smaller than that of political risk.

Fixed effect estimations in columns 4 and 5 confirm the robustness of the political corruption effect, with similar marginal effects. The direct effect of corruption, however, loses statistical significance, as country fixed effects seem to capture part of this effect, thus resting significance to the corruption and bureaucratic variables.

\footnotetext{
${ }^{32}$ I obtain similar results when replacing the index of contract repudiation by an average of this index with an index of the risk of investment expropriation.

${ }^{33}$ Different cutoff levels were tested and the one used in Table 2 (corruption index strictly less than 3.33 on the PRS scale) proved the most significant. Around $25 \%$ of the countries in the sample are below this threshold.

${ }^{34}$ Those with a value of the index less than 3.33 , which includes around $40 \%$ of the sample.
} 
Note that risk and corruption have important explanatory power, as their inclusion augments the part of the variance explained by the regression (the $R^{2}$ ) by around $15 \%$. Moreover, about half of this effect appears to be conditional on the presence of the soil resources variable, while the soil variable alone fails to rise the explanatory power of the estimations. An intuitive explanation is that this variable captures the effect of natural resources projects (oil, mining), which generally call for direct involvement from multinational firms due to the size of the fixed investment required and political strategic considerations, and are particularly prone to the kind of risk discussed in this paper.

Standard controls, openness, size and level of development, as well as inflation, are not significant in columns 1 to 3 , but become significant when allowing for country fixed effects. Richer countries receive a higher share of FDI, while the effect of more openness and bigger size are negative. Higher inflation, implying less macroeconomic stability, implies a higher relative share of FDI. As for invariant characteristics, latitude is significant in regressions 1 to 3, with countries nearer the equator receiving a higher share of FDI. Time dummies for the periods 1985-89 and 1990-94 are negative and very significant, probably indicating the recent shift towards a more favorable perception of inward FDI flows.

One potential limitation of this empirical test is that the link between the ratio of FDI to total capital flows and institutional quality variables may be due to the movement of short term capital flows, included in the left hand side variable's denominator, that may be quickly reversed in a scenario of increased institutional uncertainty. ${ }^{35}$ To test this hypothesis, Table 3 presents estimations with the ratio of FDI to private capital flows now excluding portfolio investment flows as dependent variable.

(Table 3 here)

Overall, the results again strongly support the political corruption story, while the direct effect of corruption is of the expected sign but only weakly significant. A one point increase in the risk index appears to have an average positive impact of between 3.7 and $5.4 \%$ on the share of direct investment, while the effect of corruption through its interaction with risk is again about one sixth of the direct effect.

This preliminary evidence, based on aggregate data, is therefore consistent with the model's predictions. It also qualifies previous empirical findings. Indeed, Wei and Wu (2000) conclude that "corruption in a capital-importing

\footnotetext{
${ }^{35} \mathrm{I}$ thank a referee for making this point and suggesting the robustness test below.
} 
country tends to tilt the composition of its capital inflows away from foreign direct investment and towards foreign bank loans". ${ }^{36}$ Smarzynska and Wei (2000), using firm-level data for Eastern Europe and the former Soviet Union, also find that corruption makes firms prefer a mode of entry based on a claim with less control rights (licensing). ${ }^{37}$ Our results refine these conclusions by stressing that the impact of corruption matters mostly by modifying the effect of political risk on capital flows. One hypothesis is that the importance given to the direct effect of corruption in previous studies may be due to the lack of control for political risk.

\section{Conclusion}

I have modeled the boundaries of the multinational firm, i.e. the financial structure of its involvement in a foreign country, by looking at a simple tradeoff between FDI (internal expansion) and debt (arm's length expansion), and analyzed the effects of institutional constraints in host countries, i.e. problems of commitment and, especially, corruption.

The model starts by showing that capital flows are more likely to take the form of FDI when the ability to commit of the recipient is low, because in the case of default or expropriation the firm is able to recover a greater proportion of its subsequent profit, for example by shifting back some of its production to another location. It then introduces two different aspects of corruption affecting foreign investment, namely bureaucratic and political corruption. Bureaucratic corruption is shown to favor debt against FDI, with a diminishing marginal effect as corruption increases. As for political corruption, it is effective through its interaction with the risk of repudiation variable and its sign is the opposite of the political risk effect, i.e. it favors debt. These predictions are broadly supported by cross-country panel empirical evidence.

These conclusions challenge to some extent previous results by showing that the main effect of corruption on capital flows arises through its interaction with political risk and that its marginal impact is only second order. Institutional quality matters in a complex way, but clearly political risk, in the sense of potential expropriation and lack of contractual commitment, remains the key factor affecting multinational firms' mode of entry.

\footnotetext{
${ }^{36}$ This study relies on a different sample and data set, based on bilateral capital flows data from 13 developed countries to 30 less developed one, thus obviating more developed countries as recipient. Furthermore, debt flows are restricted to bank lending statistics.

${ }^{37}$ Related results are found, among others, in Albuquerque (2003), Hausmann and Fernández-Arias (2000), Henisz (2000) and Wei (2000).
} 


\section{APPENDIX 1}

The extensive game with complete information is represented in figure 2

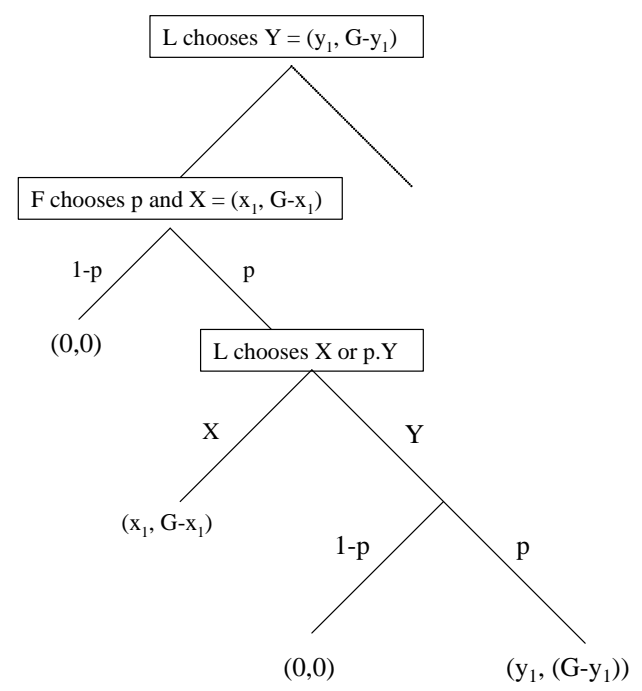

Figure 2: Extensive game

- In Stage 1: Country L proposes a payoff $y_{1}$ (implicitly a pair $Y=$ $\left(y_{1}, G-y_{1}\right)$, where $\left.y_{1} \leq G\right)$.

- In Stage 2: The Firm F replies by proposing a payoff $x_{1}$ (implicitly a pair $X=\left(x_{1}, G-x_{1}\right)$, where $\left.x_{1} \leq G\right)$, and a probability $p \in[0,1]$. With probability $1-p$ the game ends and the outcome is the status quo. With probability $p$ it continues.

- In Stage 3: Country L chooses either $X$ or the lottery p.Y (i.e. the lottery giving $Y$ with probability $p$ and the status quo with probability $1-p$ ). Its choice is the outcome.

Analyzing the game backwards, in stage 2 the firm chooses $p$ (under the constraint $p \leq 1$ ) and $x_{1}$ so as to maximize its final payoff, which is given by either $p p\left(G-y_{1}\right)$, if country L chooses $p . Y$, or $p\left(G-x_{1}\right)$ if the country's choice is $X$. Formally, the firm's program is:

$$
\begin{aligned}
& \max _{p, x_{1}}\left[\min \left(p p\left(G-y_{1}\right), p\left(G-x_{1}\right)\right)\right] \\
& \text { s.t. } \quad p \leq 1 .
\end{aligned}
$$

Anticipating that in stage 3, country L chooses between $X$ and $p . Y$ by picking the highest value between $p x_{1}$ and $p p y_{1}$, it is straightforward to see that the firm will set $p$ and $x_{1}$ such that $p x_{1}=p p y_{1}$. Indeed, there is no point in choosing $p$ and $x_{1}$ such that $p x_{1}<p p y_{1}$, since in this case $X$ will not be chosen anyway. On the other hand, if $p x_{1}>p p y_{1}, \mathrm{~F}$ can improve its 
payoff by reducing $x_{1}$ until $p x_{1}=p p y_{1}$, still ensuring country L's indifference between $X$ and $p . Y$. The firm's program thus reduces to:

$$
\begin{aligned}
& \max _{p, x_{1}}\left[p\left(G-x_{1}\right)\right] \\
& \text { s.t. } \quad x_{1}=p y_{1}, \quad p \leq 1 .
\end{aligned}
$$

Substituting for $x_{1}$, and leaving aside the constraint for the moment, this becomes:

$$
\max _{p}\left[p\left(G-p y_{1}\right)\right]
$$

which yields $p=\frac{G}{2 y_{1}}$. Taking now into account the constraint, two cases arise depending on the value of $y_{1}$. Specifically, if $y_{1} \geq \frac{G}{2}, p=\frac{G}{2 y_{1}}$ (the constraint is slack, which corresponds to the case where the firm punishes the country for setting $y_{1}$ too high, by picking a $p$ lower than 1) and $x_{1}=\frac{G}{2}$, while if $y_{1}<\frac{G}{2}, p=1$ (the constraint is now binding) and $x_{1}=y_{1}$.

Anticipating this, country L will choose $y_{1}$ in stage 1 , such that its payoff is maximal. It is straightforward to see that its optimal choice is also $y_{1}=\frac{G}{2}$, thus leading the firm to choose $x_{1}=\frac{G}{2}$ and $p=1$, so that the outcome of the game is the Nash solution $\left(\frac{G}{2}, \frac{G}{2}\right)$. Indeed, a value of $y_{1}$ less than $\frac{G}{2}$ would clearly be suboptimal, since the firm would simply choose $x_{1}=y_{1}$ and $p=1$, giving the country a lower payoff than for $y_{1}=\frac{G}{2}$. On the other hand, if the country chooses $y_{1}>\frac{G}{2}$, the firm's rule leads it to react choosing $x_{1}=\frac{G}{2}$ and $p=\frac{G}{2 y_{1}}$, giving again the country a payoff lower than $\frac{G}{2}$ (i.e. $\frac{G^{2}}{4 y_{1}}$ ).

I now turn to the extensive game with asymmetric information:

- Stage 1: Country L chooses a payoff $y_{1}$ (at this stage a pair $Y=$ $\left(y_{1}, E(G)-y_{1}\right)$, since it does not know the true value of $\left.\mathrm{G}\right)$.

- Stage 2: The Firm, knowing its type, chooses a payoff $x_{1}$ (implicitly a pair $X=\left(x_{1}, G^{R}-x_{1}\right)$, where $x_{1} \leq G^{R}$, the realized value of $G$, and $p \in[0,1]$. With probability $1-p$ the game ends and the outcome is the status quo. With probability $p$ it continues.

- Stage 3: Country L chooses either $X$ or the lottery p. $Y$ (where $Y=$ $\left.\left(y_{1}, G^{R}-y_{1}\right)\right)$. Its choice is the outcome.

As we see, the only difference with the complete information case is that in stage 1 , country $\mathrm{L}$ faces the problem of choosing $y_{1}$ such that its expected payoff conditional on the realization of the firm's type is maximum. Using the same approach as before concerning the firm's best response to any value of $y_{1}$, we see immediately the following.

If $y_{1}=\frac{G_{W}}{2}$ : 
A bad type $\left(G_{W}\right)$ chooses $x_{1}=y_{1}=\frac{G_{W}}{2}, p=1$, so the outcome is the same as in the complete information case.

A good type $\left(G_{S}\right)$ chooses $x_{1}=y_{1}=\frac{G_{W}}{2}, p=1$, (as in the complete information setting when $\left.y_{1}<\frac{G}{2}\right)$.

The total expected payoff for country L is $\nu \frac{G_{W}}{2}+(1-\nu) \frac{G_{W}}{2}=\frac{G_{W}}{2}$.

If $y_{1}=\frac{G_{S}}{2}$ :

A good type $\left(G_{S}\right)$ chooses $x_{1}=y_{1}=\frac{G_{S}}{2}, p=1$, so the outcome is the same as in the complete information case.

A bad type $\left(G_{W}\right)$ chooses $x_{1}=\frac{G_{W}}{2}, p=\frac{G_{W}}{G_{S}}$, (as in the complete information setting when $\left.y_{1}>\frac{G}{2}\right)$.

The total expected payoff for country $\mathrm{L}$ is now $\nu \frac{G_{S}}{2}+(1-\nu) \frac{G_{W}^{2}}{2 G_{S}}$.

Let us now consider the case $\frac{G_{W}}{2}<y_{1}<\frac{G_{S}}{2}$ (it is easily shown that $y_{1}<\frac{G_{W}}{2}$ and $y_{1}>\frac{G_{S}}{2}$ are dominated by $y_{1}=\frac{G_{W}}{2}$ and $y_{1}=\frac{G_{S}}{2}$ respectively).

A good type $\left(G_{S}\right)$ chooses $x_{1}=y_{1}, p=1$, (again, as in the complete information setting when $\left.y_{1}<\frac{G}{2}\right)$.

A bad type $\left(G_{W}\right)$ chooses $x_{1}=\frac{G_{W}}{2}, p=\frac{G_{W}}{2 y_{1}}$, (as in the complete information setting when $\left.y_{1}>\frac{G}{2}\right)$.

The expected payoff for country $\mathrm{L}$ is $\nu y_{1}+(1-\nu) \frac{G_{W}^{2}}{4 y_{1}}$. This payoff is a convex function of $y_{1}$, so that the value that maximizes country L's expected payoff is either $y_{1}=\frac{G_{W}}{2}$ or $y_{1}=\frac{G_{S}}{2}$ depending on the values of $\nu, G_{W}$ and $G_{S}$. Simple computations show that there is a threshold value $\nu^{*}=\frac{G_{W}}{G_{S}+G_{W}}$. For $\nu<\nu^{*}, y_{1}=\frac{G_{W}}{2}$, while for $\nu \geq \nu^{*}, y_{1}=\frac{G_{S}}{2}$, yielding the outcome described in the text.

\section{APPENDIX 2}

Figure A1 presents the information structure with supervision.

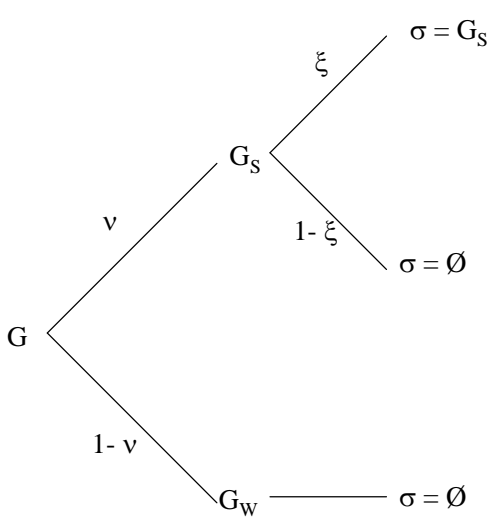

Figure A1 
To see the effect of asymmetric information, we have to use the decomposition of the project's payoff into its two period components:

$$
\begin{aligned}
G_{S} & =G_{1}+G_{2, S} \\
G_{W} & =G_{1}+G_{2, W} .
\end{aligned}
$$

When $\nu \leq \frac{G_{W}}{G_{S}+G_{W}}$, the firm's payoffs from engaging in debt and FDI become (the subscripts CI and AI denote complete information and asymmetric information respectively):

$$
\begin{aligned}
U_{S, D E B T, C I}^{F} & =\frac{1}{2} G_{1}+\frac{1}{2}(1-\gamma) G_{2, S} \\
U_{S, D E B T, A I}^{F} & =\frac{1}{2} G_{1}+\frac{1}{2}(1-\gamma)\left(G_{2, S}+\Delta G_{2}\right) \\
U_{W, D E B T}^{F} & =\frac{1}{2} G_{1}+\frac{1}{2}(1-\gamma) G_{2, W},
\end{aligned}
$$

and

$$
\begin{aligned}
U_{S, F D I, C I}^{F} & =\frac{1}{2}\left(G_{1}-K\right)+\frac{1}{2}(1-\gamma) G_{2, S}+\gamma \theta \Pi_{2, S}^{F} \\
U_{S, F D I, A I}^{F} & =\frac{1}{2}\left(\left(G_{1}-K\right)+\frac{1}{2}(1-\gamma)\left(G_{2, S}+\Delta G_{2}\right)+\gamma \theta \Pi_{2, W}^{F}\right. \\
U_{W, F D I}^{F} & =\frac{1}{2}\left(G_{1}-K\right)+\frac{1}{2}(1-\gamma) G_{2, W}+\gamma \theta \Pi_{2, W}^{F} .
\end{aligned}
$$

Note that in $U_{S, F D I, A I}^{F}$ the last term $\gamma \theta \Pi_{2, W}^{F}$ reflects the fact that the good type investor is taking advantage of the asymmetry of information to mimic the bad type and have a better status quo position in the renegotiation. The three payoffs above are received by the firm with respective probabilities $\nu \xi$, $\nu(1-\xi)$, and $1-\nu$. Simple computations yield the trade-off:

$$
F D I \succ D e b t \Leftrightarrow \gamma\left(\nu \xi \theta \Pi_{2, S}^{F}+(1-\nu \xi) \theta \Pi_{2, W}^{F}\right)-\frac{K}{2}>0 .
$$

When $\nu>\frac{G_{W}}{G_{S}+G_{W}}$, the payoffs are:

$$
\begin{aligned}
U_{S, D E B T, C I}^{F} & =\frac{1}{2} G_{1}+\frac{1}{2}(1-\gamma) G_{2, S} \\
U_{S, D E B T, A I}^{F} & =\frac{1}{2} G_{1}+\frac{1}{2}(1-\gamma) G_{2, S} \\
U_{W, D E B T}^{F} & =\frac{1}{2} G_{1}+\frac{1}{2}(1-\gamma) \frac{G_{2, W}^{2}}{G_{2, S}},
\end{aligned}
$$


and

$$
\begin{aligned}
U_{S, F D I, C I}^{F} & =\frac{1}{2}\left(G_{1}-K\right)+\frac{1}{2}(1-\gamma) G_{2, S}+\gamma \theta \Pi_{2, S}^{F} \\
U_{S, F D I, A I}^{F} & =\frac{1}{2}\left(G_{1}-K\right)+\frac{1}{2}(1-\gamma) G_{2, S}+\gamma \theta \Pi_{2, S}^{F} \\
U_{W, F D I}^{F} & =\frac{1}{2}\left(G_{1}-K\right)+\frac{1}{2}(1-\gamma) \frac{G_{2, W}^{2}}{G_{2, S}}+\gamma \theta \Pi_{2, W}^{F} .
\end{aligned}
$$

Note that now the firm has revealed its type in period 1 by choosing between $x_{1}=y_{1}=\frac{G_{S}}{2}, p=1$, and $x_{1}=\frac{G_{W}}{2}, p=\frac{G_{W}}{G_{S}}$, so a good type has no scope for pretending being a bad type in the second period renegotiation. Similar computations as before show that in this case the trade-off is the same as under complete information.

Consider finally an information structure where the politician also receives information on the bad type project. The revelation of this piece of information allows the implementation of the complete information solution, so the efficiency loss is avoided. The politician might then threaten the firm not to reveal its information in exchange for a share of the potential gain ("give me $\alpha\left(\frac{G_{W}}{2}-\frac{G_{2, W}^{2}}{G_{2, S}}\right)$ or I don't reveal you are $G_{W}$.") For the same reason as before, the FDI vs. debt trade-off is not altered by this potential extortion.

\section{APPENDIX 3}

Countries in the sample: Algeria, Angola, Argentina, Australia, Austria, Bahamas, Bahrain, Bangladesh, Belgium, Bolivia, Botswana, Brazil, Bulgaria, Burkina Faso, Cameroon, Canada, Chile, China, Colombia, Costa Rica, Cyprus, Czech Republic, Denmark, Dominican Republic, Ecuador, Egypt, El Salvador, Finland, France, Gabon, Gambia, Germany, Ghana, Greece, Guatemala, Guinea, Guyana, Haiti, Honduras, Hungary, Iceland, India, Indonesia, Iran, Ireland, Israel, Italy, Jamaica, Japan, Jordan, Kenya, Korea, Kuwait, Libya, Malawi, Malaysia, Mali, Malta, Mexico, Mongolia, Morocco, Mozambique, Myanmar, Namibia, Netherlands, New Zealand, Niger, Nigeria, Norway, Oman, Pakistan, Panama, Papua New Guinea, Peru, Philippines, Poland, Portugal, Romania, Russian, Saudi Arabia, Senegal, Sierra Leone, Singapore, Slovak Republic, South Africa, Spain, Sri Lanka, Sudan, Suriname, Sweden, Switzerland, Syria, Tanzania, Thailand, Togo, Trinidad, Tunisia, Turkey, Uganda, United Kingdom, United States, Uruguay, Venezuela, Yemen, Zambia, Zimbabwe. 


\section{REFERENCES}

Albuquerque, R., 2003, "The Composition of International Capital Flows: Risk Sharing Through Foreign Direct Investment", Journal of International Economics, 61(2), 353-383.

Blomström, M. and A. Kokko, 1996, "Multinational Corporations and Spillovers", Discussion Paper 1365, Center for Economic Policy Research.

Bond, E. and L. Samuelson, 1989, "Bargaining with Commitment, Choice of Techniques, and Direct Foreign Investment", Journal of International Economics, 26, 77-97.

Doyle, C. and S. Van Wijnbergen, 1994, "Taxation of Foreign Multinationals: A Sequential Bargaining Approach to Tax Holidays", International Tax and Public Finance 1(3), 211-225.

Eaton, J. and R. Fernandez, 1995, "Sovereign Debt", in: G. Grossman and K. Rogoff, eds., Handbook of International Economics, vol. III, (NorthHolland, Amsterdam), 2031-2077.

Eaton, J. and M. Gersovitz, 1984, "A Theory of Expropriation and Deviations from Perfect Capital Mobility", Economic Journal, 94, 16-40.

Fosfuri, A., 2000, "Patent Protection, Imitation and the Mode of Technology Transfer", International Journal of Industrial Organization, 18(7), 1129-1149.

Hart, O., 1995, Firms, Contracts, and Financial Structure, Clarendon Lectures, Oxford University Press.

Hart, O. and J. Moore., 1990, "Property Rights and the Nature of the Firm", Journal of Political Economy 98, 1119-58.

Hausmann, R. and E. Fernández-Arias., 2000, "Foreign Direct Investment: Good Cholesterol?", Working Paper 417 IDB research dept.

Henisz, W., 2000, "The Institutional Environment for Multinational Investment", Journal of Law, Economics, \& Organization, 16(2), 334-364.

Hines, J, Jr, 1995, "Forbidden Payment: Foreign Bribery and American Business after 1977", NBER Working paper 5266, Cambridge, MA.

Howard, J.V., 1992, "A Social Choice Rule and Its Implementation in Perfect Equilibrium", Journal of Economic Theory, 56, 142-159.

Goldstein, I. and A. Razin, 2003, "An Information-Based Trade Off Between Foreign Direct Investment and Foreign Portfolio Investment: Volatility, Transparency, and Welfare", NBER Working paper 9426, Cambridge, MA.

Janeba, E., 2002, "Attracting FDI in a Politically Risky World", International Economic Review 43(4), 1127-1155.

Kaufmann, D., 2004, "Corruption, Governance and Security: Challenges for the Rich Countries and the World", in Global Competitiveness Report 2004-2005, Palgrave Macmillan. 
Kraay, A., Loayza, N., Servén, L. and Ventura, J., 2005, "Country Portfolios", Journal of the European Economic Association, 3(4), 914-945.

Krugman, P., 1995, "Increasing Returns, Imperfect Competition and the Positive Theory of International Trade", in: G. Grossman and K. Rogoff, eds., Handbook of International Economics, vol. III, North-Holland, Amsterdam, 1243-1277.

Laffont, J.J. and J. Tirole, 1993, A Theory of Incentives in Procurement and Regulation, Third Printing, MIT Press.

Laffont, J.J. and J. Tirole., 1991, "The Politics of Government Decision Making: A Theory of Regulatory Capture", Quarterly Journal of Economics 107, 1089-1127.

Markusen, J.R., 1995, "The Boundaries of Multinational Enterprises and the Theory of International Trade", Journal of Economic Perspectives 9(2), 169-189.

Moran, T., 1998, Foreign Direct Investment and Development, The New Policy Agenda for Developing Countries and Economies in Transition, Institute for International Economics, Washington D.C.

Morisset, J. P. and Lumenga-Neso, O., 2002, "Administrative Barriers to Foreign Investment in Developing Countries", World Bank Policy Research Working Paper 2848.

Osborne M. and A. Rubinstein.,1994, A Course in Game Theory, MIT Press.

Rose-Ackerman, S., 1999, Corruption and Government: Causes, Consequences, and Reform, Cambridge University Press.

Schnitzer. M., 2002, "Debt versus Foreign Direct Investment: The Impact of Sovereign Risk on the Structure of International Capital Flows", Economica 69(273), 41-67.

Smarzynska, B.K. and S-J. Wei., 2000, "Corruption and Composition of Foreign Direct Investment: Firm-Level Evidence", NBER Working paper 7969, Cambridge, MA.

Tirole J., 2003, "Inefficient Foreign Borrowing: A Dual-and CommonAgency Perspective", American Economic Review, 93(5), 1678-1702.

Tirole J., 1992, "Collusion and the Theory of Organizations", In. J.J. Laffont, ed., Advances in Economic Theory, Sixth World Congress, Vol. 2., Cambridge University Press, New York.

Wei, S-J., 2000, "How Taxing is Corruption on International Investors?", Review of Economics and Statistics, 82(1): 1-11.

Wei, S-J. and Wu Y., 2000, "Corruption, Composition of Capital Flows, and Currency Crises", World Bank Policy Research Working Paper 2429.

Williamson, O., 1975, Markets and Hierarchies, The Free Press, New York. 
Table 2. Dependent variable: Ln (FDI / Total capital flows)

\begin{tabular}{|c|c|c|c|c|c|}
\hline Sample & Panel 1985-99 & Panel 1985-99 & Panel 1985-99 & Panel 1985-99 & Panel 1985-99 \\
\hline Estimation method & $\begin{array}{l}\text { No intercept. } \\
\text { Time and } \\
\text { regional } \\
\text { dummies. }\end{array}$ & $\begin{array}{l}\text { No intercept. } \\
\text { Time and } \\
\text { regional } \\
\text { dummies. }\end{array}$ & $\begin{array}{l}\text { No intercept. } \\
\text { Time and } \\
\text { regional } \\
\text { dummies. }\end{array}$ & $\begin{array}{c}\text { Fixed effects. } \\
\text { Time } \\
\text { dummies. }\end{array}$ & $\begin{array}{c}\text { Fixed effects. } \\
\text { Time } \\
\text { dummies. }\end{array}$ \\
\hline & $(1)$ & $(2)$ & (3) & (4) & (5) \\
\hline Ln GDP per capita & $\begin{array}{l}-0.002 \\
(0.014)\end{array}$ & $\begin{array}{l}-0.006 \\
(0.015)\end{array}$ & $\begin{array}{c}0.003 \\
(0.014)\end{array}$ & $\begin{array}{c}0.161 * * * \\
(0.051)\end{array}$ & $\begin{array}{c}0.158^{* * *} \\
(0.046)\end{array}$ \\
\hline Ln Imports/GDP & $\begin{array}{c}0.129 \\
(0.256)\end{array}$ & $\begin{array}{c}0.086 \\
(0.247)\end{array}$ & $\begin{array}{c}0.070 \\
(0.259)\end{array}$ & $\begin{array}{l}-1.213^{* *} \\
(0.526)\end{array}$ & $\begin{array}{l}-1.280 * * \\
(0.534)\end{array}$ \\
\hline Ln GDP & $\begin{array}{l}-0.018 \\
(0.068)\end{array}$ & $\begin{array}{c}0.014 \\
(0.072)\end{array}$ & $\begin{array}{l}-0.051 \\
(0.060)\end{array}$ & $\begin{array}{l}-0.922 * \\
(0.479)\end{array}$ & $\begin{array}{l}-1.018 * * \\
(0.450)\end{array}$ \\
\hline Soil ressources & $\begin{array}{l}0.149 * * \\
(0.070)\end{array}$ & $\begin{array}{c}0.151^{* *} \\
(0.070)\end{array}$ & $\begin{array}{l}0.143^{*} \\
(0.083)\end{array}$ & & \\
\hline Latitude & $\begin{array}{l}-1.752 * * \\
(0.727)\end{array}$ & $\begin{array}{c}-2.025^{* * *} \\
(0.764)\end{array}$ & $\begin{array}{l}-1.531 * * \\
(0.723)\end{array}$ & & \\
\hline Inflation & $\begin{array}{l}-0.346 \\
(1.287)\end{array}$ & $\begin{array}{c}0.166 \\
(1.230)\end{array}$ & $\begin{array}{l}-0.494 \\
(1.300)\end{array}$ & $\begin{array}{l}2.546 * * \\
(1.260)\end{array}$ & $\begin{array}{l}2.543^{* *} \\
(1.273)\end{array}$ \\
\hline $\begin{array}{l}\text { Risk of contract } \\
\text { repudiation }\end{array}$ & $\begin{array}{l}0.297^{*} \\
(0.159)\end{array}$ & $\begin{array}{c}0.311^{* *} \\
(0.156)\end{array}$ & $\begin{array}{c}0.391 * * * \\
(0.143)\end{array}$ & $\begin{array}{c}0.432 * * * \\
(0.150)\end{array}$ & $\begin{array}{l}0.312^{* *} \\
(0.149)\end{array}$ \\
\hline Corruption & $\begin{array}{l}-0.143^{*} \\
(0.083)\end{array}$ & $\begin{array}{l}-0.166^{*} \\
(0.085)\end{array}$ & & $\begin{array}{c}0.107 \\
(0.092)\end{array}$ & \\
\hline $\begin{array}{l}\text { Corruption } * \text { dummy } \\
\text { low corruption }\end{array}$ & & $\begin{array}{l}-0.230 * \\
(0.121)\end{array}$ & & $\begin{array}{l}-0.058 \\
(0.083)\end{array}$ & \\
\hline Bureaucratic quality & & & $\begin{array}{c}0.016 \\
(0.049)\end{array}$ & & $\begin{array}{l}-0.104 \\
(0.109)\end{array}$ \\
\hline $\begin{array}{l}\text { Bureaucratic quality * } \\
\text { dummy low bur. qual }\end{array}$ & & & $\begin{array}{l}-0.103^{*} \\
(0.054)\end{array}$ & & $\begin{array}{l}-0.009 \\
(0.095)\end{array}$ \\
\hline Risk $*$ Corruption & $\begin{array}{l}-0.051^{*} \\
(0.029)\end{array}$ & $\begin{array}{l}-0.054 * \\
(0.029)\end{array}$ & $\begin{array}{c}-0.080^{* * *} \\
(0.023)\end{array}$ & $\begin{array}{c}-0.073^{* * *} \\
(0.023)\end{array}$ & $\begin{array}{c}-0.047 * * \\
(0.021)\end{array}$ \\
\hline $\mathbf{N}$ & 136 & 136 & 136 & 201 & 201 \\
\hline $\mathbf{R}^{2}$ & 0.37 & 0.39 & 0.37 & 0.71 & 0.70 \\
\hline
\end{tabular}

White Heteroskedasticity-consistent standard errors in parentheses.

Results significant at the $1 \%(* *), 5 \%(* *)$ and $10 \%(*)$.

Regional dummies included: Latin America and Caribbean, Sub-Saharan Africa, Asia, Middle East and North Africa, Most Developed Countries (Europe, North America, Australia and New Zealand).

Estimates for time and regional dummies are not reported. 
Table 3. Dependent variable: Ln (FDI / Total capital flows excluding portfolio investment flows)

\begin{tabular}{|c|c|c|c|c|c|}
\hline Sample & Panel 1985-99 & Panel 1985-99 & Panel 1985-99 & Panel 1985-99 & Panel 1985-99 \\
\hline Estimation method & $\begin{array}{l}\text { No intercept. } \\
\text { Time and } \\
\text { regional } \\
\text { dummies. }\end{array}$ & $\begin{array}{l}\text { No intercept. } \\
\text { Time and } \\
\text { regional } \\
\text { dummies. }\end{array}$ & $\begin{array}{l}\text { No intercept. } \\
\text { Time and } \\
\text { regional } \\
\text { dummies. }\end{array}$ & $\begin{array}{c}\text { Fixed effects. } \\
\text { Time } \\
\text { dummies. }\end{array}$ & $\begin{array}{c}\text { Fixed effects. } \\
\text { Time } \\
\text { dummies. }\end{array}$ \\
\hline & $(1)$ & $(2)$ & (3) & (4) & (5) \\
\hline Ln GDP per capita & $\begin{array}{c}0.013 \\
(0.018)\end{array}$ & $\begin{array}{c}0.008 \\
(0.020)\end{array}$ & $\begin{array}{c}0.017 \\
(0.018)\end{array}$ & $\begin{array}{c}0.177 * * * \\
(0.047)\end{array}$ & $\begin{array}{c}0.160 * * * \\
(0.042)\end{array}$ \\
\hline Ln Imports/GDP & $\begin{array}{l}-0.025 \\
(0.329)\end{array}$ & $\begin{array}{l}-0.038 \\
(0.319)\end{array}$ & $\begin{array}{l}-0.079 \\
(0.337)\end{array}$ & $\begin{array}{c}-1.559 * * * \\
(0.515)\end{array}$ & $\begin{array}{l}-1.665^{* * * *} \\
(0.523)\end{array}$ \\
\hline Ln GDP & $\begin{array}{c}0.012 \\
(0.070)\end{array}$ & $\begin{array}{c}0.040 \\
(0.076)\end{array}$ & $\begin{array}{l}-0.013 \\
(0.065)\end{array}$ & $\begin{array}{c}-1.102^{* *} \\
(0.491)\end{array}$ & $\begin{array}{c}-1.144 * * \\
(0.482)\end{array}$ \\
\hline Soil ressources & $\begin{array}{c}0.103 \\
(0.087)\end{array}$ & $\begin{array}{c}0.108 \\
(0.087)\end{array}$ & $\begin{array}{c}0.100 \\
(0.095)\end{array}$ & & \\
\hline Latitude & $\begin{array}{l}-1.454 * \\
(0.823)\end{array}$ & $\begin{array}{c}-1.712 * * \\
(0.820)\end{array}$ & $\begin{array}{l}-1.308 \\
(0.807)\end{array}$ & & \\
\hline Inflation & $\begin{array}{l}-1.488 \\
(1.701)\end{array}$ & $\begin{array}{l}-1.114 \\
(1.606)\end{array}$ & $\begin{array}{l}-1.566 \\
(1.683)\end{array}$ & $\begin{array}{c}0.997 \\
(1.494)\end{array}$ & $\begin{array}{c}0.932 \\
(1.512)\end{array}$ \\
\hline $\begin{array}{l}\text { Risk of contract } \\
\text { repudiation }\end{array}$ & $\begin{array}{l}0.379 * * \\
(0.166)\end{array}$ & $\begin{array}{l}0.386 * * \\
(0.165)\end{array}$ & $\begin{array}{c}0.431 * * * \\
(0.152)\end{array}$ & $\begin{array}{c}0.544 * * * \\
(0.155)\end{array}$ & $\begin{array}{l}0.365^{* *} \\
(0.157)\end{array}$ \\
\hline Corruption & $\begin{array}{l}-0.077 \\
(0.078)\end{array}$ & $\begin{array}{l}-0.098 \\
(0.081)\end{array}$ & & $\begin{array}{l}0.186^{*} \\
(0.101)\end{array}$ & \\
\hline $\begin{array}{l}\text { Corruption } * \text { dummy } \\
\text { low corruption }\end{array}$ & & $\begin{array}{l}-0.192 \\
(0.132)\end{array}$ & & $\begin{array}{c}0.024 \\
(0.107)\end{array}$ & \\
\hline Bureaucratic quality & & & $\begin{array}{c}0.028 \\
(0.059)\end{array}$ & & $\begin{array}{l}-0.171 * \\
(0.101)\end{array}$ \\
\hline $\begin{array}{l}\text { Bureaucratic quality * } \\
\text { dummy low bur. qual }\end{array}$ & & & $\begin{array}{l}-0.064 \\
(0.058)\end{array}$ & & $\begin{array}{l}-0.040 \\
(0.098)\end{array}$ \\
\hline Risk $*$ Corruption & $\begin{array}{c}-0.068^{* *} \\
(0.030)\end{array}$ & $\begin{array}{c}-0.069 * * \\
(0.030)\end{array}$ & $\begin{array}{c}-0.086^{* * * *} \\
(0.025)\end{array}$ & $\begin{array}{c}-0.090 * * * \\
(0.023) \\
\end{array}$ & $\begin{array}{c}-0.050 * * \\
(0.020)\end{array}$ \\
\hline $\mathbf{N}$ & 131 & 131 & 131 & 196 & 196 \\
\hline $\mathbf{R}^{2}$ & 0.36 & 0.37 & 0.37 & 0.74 & 0.74 \\
\hline
\end{tabular}

White Heteroskedasticity-consistent standard errors in parentheses.

Results significant at the $1 \%(* * *), 5 \%(* *)$ and $10 \%(*)$.

Regional dummies included: Latin America and Caribbean, Sub-Saharan Africa, Asia, Middle East and North Africa, Most Developed Countries (Europe, North America, Australia and New Zealand).

Estimates for time and regional dummies are not reported. 